\title{
Pereajalugu internetiajastul: diasporaa-genealoogia ja jätkuv ajalookirjutusprotsess
}

\begin{abstract}
Anne Heimo
Teesid: Artiklis käsitletakse pereajaloo viljelemise uusi vorme internetiajastul. Suguvõsauurimine on viimase kahe aastakümne jooksul muutunud üheks populaarsemaks harrastuseks. Samal ajal toimunud infotehnoloogia areng on võimaldanud huvi suurenemist pereajaloo vastu veelgi, kusjuures eriti just nn üle-piiri-peredele ehk hargmaistele peredele on muutus olnud murranguline ja inimesed otsivad oma suguvõsa juuri mitte ainult oma kodumaalt, vaid ka sugulaste kodumaalt kogu maakeral. Artiklis vaadeldakse teemat eeskätt Austraaliasse siirdunud Soome väljarändajate näitel. Austraalias on paljud mälestustega tegelevad organisatsioonid, arhiivid ja muuseumid, samuti institutsioonidest sõltumatud projektid hakanud aktiivselt koguma pereajalugusid ja väljarändajate mälestusi, käsitledes seda kui osa riigi mitmekultuurilisuse poliitikast.
\end{abstract}

Märksõnad: Austraalia-soomlased, diasporaa-genealoogia, osaluskultuur, pereajalugu, perepärimus, suguvõsauurimine, spontaanne ajalookirjutusprotsess

Inimesed tunnevad jätkuvalt huvi oma pere ja suguvõsa mineviku vastu ning pereajaloost ja suguvõsauurimisest on viimase kahe aastakümnega saanud üks populaarsemaid harrastusi. ${ }^{1}$ Samal ajal toimunud infotehnoloogia areng, eeskätt interneti ja sotsiaalmeedia läbimurre, on seda populaarsuse kasvu omalt poolt mõjutanud. Huvilistele on kasutamiseks saadaval arvukaid ärilisi teenuseid (de Groot 2009: 73; Meethan 2008; Rosenzweig \& Thelen 1998). Soomes on kümneid suguvõsauuringutega tegelevaid ühinguid ning hinnanguliselt tuhatkond suguvõsaseltsi ja -ühingut. ${ }^{2}$ Suguvõsauurimusi ilmub rohkem kui kunagi varem. Soome rahvusringhäälingu Yleisradio (Yle) televisiooniprogrammis esitati hiljuti tuntud BBC telesarja "Who do you think you really are" soomepärast versiooni "Kuka oikein olet?" (Kes sa õieti oled?), ${ }^{3}$ kus tuntud soomlased otsisid oma suguvõsa juuri. Retked kodukanti on alati olnud populaarsed. Nüüd aga võib juba rääkida eraldi turismiliigist, juurte-turismist (roots-tourism). Perepärimuse ja oma juurte vastu huvi tundvatele inimestele pakutakse erireise, mille eesmärk on anda võimalusi tutvuda esivanemate 
elukohtadega ning õppida reisi ajal tundma oma suguvõsa ajalugu (Basu 2005; Timothy 2008; Nash 2008: 15, 68-69). Eeskätt suviti tuleb Soome rohkesti aastakümnete eest Põhja-Ameerikasse ja Austraaliasse siirdunud väljarändajate järeltulijaid. Karjalast pärast Teist maailmasõda Soome evakueerunud karjalased ja nende lapsed lähevad omakorda suurte rühmadena endistesse kodukohtadesse meenutama - ja mõni neist ehk ka taga nutma - suguvõsa kunagisi maavaldusi (vt nt Fingerroos 2007; Lehto \& Timonen 1993).

Välismaal näikse huvi pereajaloo vastu olevat veelgi suurem kui Soomes. Ameerika Ühendriikides, Kanadas, Suurbritannias ja Austraalias innustavad arhiivid, muuseumid ja teised avalikud organisatsioonid, isegi telekompaniid ${ }^{4}$ inimesi uurima oma pereajalugu, avaldades suguvõsauurimise käsiraamatuid ja korraldades ettevõtmisi pereajaloo huvilistele. Kanadas on üle poole arhiiviotsingutest seotud suguvõsauurimustega (Creet 2011: 3). Austraalias hakati alates 2007. aastast tähistama rahvuslikku pereajaloo nädalat. 2012. aastal pikendati ürituse kestust ühe kuuni, kui augustis toimus nn pereajaloo kuu (National Family History Month): kuu aja kestel korraldati mitmel pool sündmusi, mille raames kutsuti inimesi üles tegelema pereajalooga, julgustades neid näiteks suguvõsa ajalooga tegelevate seltsidega ühendust võtma, kirjutama omaelulugusid või intervjueerima sugulasi, korraldama suguvõsa kokkutulekuid või pereajalugu tutvustavaid üritusi, süstematiseerima perekonnafotosid või külastama suguvõsale tähtsaid kohti (http://www. familyhistoryweek.org.au/celebrate). Põhjus, miks pereajaloole nii palju tähelepanu pööratakse, peitub osaliselt nende riikide mitmekultuurilisuses. Oma juurte tundmist on peetud vahendiks, mis aitab saabujail koduneda ja kohalikul elanikkonnal teadvustada mujalt tulnute ajalugu (vt nt Creet 2011; Henrich 2013).

Hoolimata pereajaloo vastu tuntava huvi ulatuslikkusest on selle akadeemiline uurimine siiski veel tagasihoidlik (Meethan 2008; Kramer 2011a: 429), kuigi uurijate teaduslik huvi nende endi pereajaloo vastu on tõusnud (Srigley \& Zembryski 2009: 10). Viimast suundumust iseloomustavateks töödeks on nt Carolyn Steedmani Landscape for a Good Women (1986), Annette Kuhni Family Secrets: Acts of Memory and Imagination (2002, 1. korda 1995) ja Marianne Hirschi Family Frames: Photography, Narrative, and Postmemory (1997) (vt samuti selles artiklis mainitud Smart 2007; Fingerroos 2007). Ka huvi hargmaiste perede ${ }^{5}$ ajaloo vastu on kasvanud ning mõnedki pärimusliku ajaloo ja mälu-uurijad on seda ala käsitlenud (vt nt Chamberlain \& Leydersdorff 2004: 228-229; Thomson 2011). Ka minu enda huvi pereajaloo, ja just Austraalia-soomlaste pereajaloo vastu, on alguse saanud isiklikust taustast. Olen lapsepõlve veetnud Austraalias ning kasvades kuulnud oma vanemate ja teiste Austraaliasse ümberasunute jutustusi väljarändamisest. 
Viimase kahekümne aasta kestel toimunud infotehnoloogia areng on teatud viisil kujundanud pereajalooga tegelemist. Eriti just mitme riigi perede seisukohalt on muutus olnud murranguline ja tekitanud nähtuse, mida Catherine Nash (2008: 15) nimetab diasporaa-genealoogiaks (diasporic genealogy). Inimesed otsivad suguvõsa juuri mitte ainult oma kodumaalt, vaid ka sugulaste kodumaadelt maailma erinevatest osadest.

1990. aastatest alates, paralleelselt infotehnoloogia arenguga on folkloorset materjali digiteeritud ja kogutud nii arhiivide andmebaasidesse kui ka veebilehtedele. Sellest hoolimata on folkloristid, väljaarvatud üksikud erandid, internetipärimust või inimeste spontaanset interneti-tegevust oma tegevusväljale toonud üsna aeglaselt (vt nt Blank 2009; Blank 2012; Heimo 2011), ehkki etnograaf Robert Kozinets (2010: 2-3) on juba aastaid tagasi põhjendatult küsinud, kas tänapäeva inimesi ja ühinguid on üldse võimalik uurida nii, et ei uuritaks ühtlasi nende tegevust võrgus. Ameerika Ühendriikide kõrval on internet siiski juba 1990. aastatest alates olnud folkloristliku uurimuse objektiks Eestis (vt nt Kõiva \& Vesik 2009). Eriti huvipakkuv uue uurimisala hõlmamise näide siinse uurimuse vaatepunktist on Mare Kõiva (2008) artikkel Austraalia-eestlaste internetikasutusest ja selle tähendusest neile. Kuigi folkloristlikke internetiuurimusi tasahaaval lisandub, pean käesolevas artiklis praegu veel tuginema teistes valdkondades, eeskätt suulise ajaloo ja mälu-uuringute, meedia- ja kultuuripärandi uurimise valdkonnas tehtule, ning mõistagi internetietnograafiale. Internetietnograafia - välitööd võrgus, uurimus võrgust või võrgu vahendusel - on keeruline ala, sest internet on oma loomult dünaamiline ja sel võib kasutajate silmis olla erinevaid tähendusi olenevalt sellest, milliseid teenuseid või rakendusi nad kasutavad (vt nt Hine 2000; Suominen 2009; Laaksonen jt 2013). Lisaks uurimistöö üldistele eetikareeglitele tuleb arvestada interneti selliste iseärasustega nagu avalikkuse ja privaatsuse ebamäärasus või aja ja koha tähenduste muutus. Paljud internetietnograafid on seadnud kahtluse alla uurijate üldise tava lihtsalt jälgida veebilehti, enda juuresviibimist avalikustamata (Turtainen \& Östman 2013). Olen siiski ka ise niiviisi toiminud, sest vaadeldavad veebilehed on olnud avatud või poolavatud, mida saab jälgida nendega liitumata (ehkki minu palvel on mind neisse vastu võetud). Neil veebilehtedel ei käsitleta ka eriti delikaatseid teemasid.

Käesolevas artiklis vaatlen pereajaloo viljelemise tänapäevaseid, sh eriti uusi vorme. ${ }^{6}$ Esmalt teen kokkuvõtte praegusest pereajaloo buumist ja sellega seonduvatest uurimustest üldisemalt. Käsitlen ka pereajaloo suhet pärimusliku ajaloo ja mälu-uuringutega. Seejärel vaatlen pereajaloo-esitusi internetis. Lõpuks tutvustan ümberasujate mälestuste talletamist Austraalias, näidates ühtlasi, mil viisil on Austraalia-soomlased ümberasumist kirjeldanud. 


\section{Genealoogia ja pereajalugu}

Maailma suurimate genealoogiaalaste veebilehtede hulka kuuluv Ancestry.com küsis 2012. aasta sügisel oma Facebooki-lehel, ${ }^{7}$ miks inimesed tunnevad oma pereajaloo vastu huvi. Mõne päeva jooksul kogunes küsimusele vastajaid 151. Paljud rääkisid, et nad on uudishimulikud ja soovivad rohkem teada saada oma päritolust, mõnest sugulasest - paljud adopteeritud teatasid, et otsivad teavet oma bioloogiliste esivanemate kohta - või otsiti selgitust peresaladustele. Osa vastajaist tundis kohustust koguda pereajalooalast materjali ja seda tulevastele põlvedele edasi anda. Oli ka neid, kelle huvi oli puhtpraktiline - nad soovisid parandada arhiivides esinevaid vigu või kontrollida, kas suguvõsas leidub pärilike haiguste kandjaid või miks mitte ka rikkaid sugulasi, kellelt võiks oodata pärandust, nagu mõni vastaja samuti naljatlevalt märkis. Need vastused on kooskõlas pereajaloo põhjuseid käsitlevates uurimustes saadud tulemustega. (Kramer 2011b; Rosenzweig \& Thelen 1998: 15-16, 25.)

Huvi pere- ja suguvõsaajaloo vastu on oluliselt kasvanud sellestki hoolimata - või just sellepärast -, et läänemaades on tuumperede (vanemad ja lapsed) tähtsus vähenenud. ${ }^{8}$ Uurijad on seda seletanud mitmeti. Huvi lisandumist on peetud vastureaktsiooniks tänapäevale, millele peetakse omaseks kollektiivsuse puudumist, individuaalsuse rõhutamist, liikuvat eluviisi, peresidemete nõrgenemist ja tuumperede arvulist vähenemist. Pere- ja suguvõsaajaloos nähakse eneseuuringu, mõistmise ja identiteedi loomise vahendit. Oma juurte tundmist loetakse eelduseks, et inimene saaks kogeda ennast eheda ja terviklikuna. Suguvõsaajaloost otsitakse vastuseid küsimusele, miks on asjad nii, nagu nad on, ja positiivseid eeskujusid, kellega samastuda: miks mina olen selline?, miks minu pere on selline? Huvi põhjustena on välja toodud ka üldiseks muutunud vajadust ajalugu personaliseerida. Pereajaloo-uurimustest tõusevad esile ühtaegu nii kollektiivsus kui ka individuaalsus, nii üheskoos kui ka lahus olemine. (Vt nt Ashton \& Hamilton 2007: 27-28; Srigley \& Zembryski 2009; Kramer 2011b.)

Esialgu oli sugupuude väljaselgitamine seotud pärandi-ja maaomandiõiguse ning oma seisundi tugevdamisega, puudutades peamiselt kõrgkihti ja mehi. Tänapäeval soovivad ka paljud nii-öelda tavalised inimesed, olenemata oma soost, tutvuda suguvõsaajalooga, lootmata leida sealt suurmehi või -naisi, ehkki ka see võimalus võib mõnele huvi pakkuda. (Vt Hareven 1992: 271; Smart 2007: 36.)

Pereajalugu on siinses käsitluses laiem mõiste kui suguvõsauurimus, ehkki mõlemad hõlmavad sugulussuhete ja suguvõssa kuuluvate isikute ajaloolise põlvnemise uurimist. Suguvõsauurimise esmane eesmärk on kirikuraamatute ja teiste ametlike perekonnalooliste dokumentide abil välja selgitada ning kokku panna sugupuu. Pereajaloos otsitakse mitmeid meetodeid kasutades teavet suguvõsa ajaloo kohta, kusjuures huvi võib olla nii biograafiline kui ka kodulooga 
seotud. See võib olla suunatud näiteks suguvõsa sõjaväelastest isikutele või väljarännanud pereliikmetele. Pereajaloo-uurija allikad on perepärimus, kirjad, päevikud ja muud autobiograafilised materjalid, fotod, ajaleheväljalõiked, mälestused, kodu-uurimisega seotud kirjandus. Pereajaloo-uurija võib sugupuu või tabeli koostamise asemel kirjutada raamatu, pidada ettekande suguvõsa kokkutulekul, koostada leidudest näituse või hakata haldama veebilehte. Genealoogias on traditsiooniliselt eelistatud meesliine, pereajaloos jaotub huvi nii naiste kui ka meeste vahel (Latvala 2005: 77; vt ka Jaago 2002: 422-423). Faktide väljaselgitamine ning lahkunud sugulaste otsimine ja leidmine on tähtis nii suguvõsa- kui ka pereajaloo uurijale. Samuti iseloomustab mõlemat valdkonda vajadus leida endale ja oma pere liikmetele koht ajas ja ruumis, ühtlasi kohusetunne säilitada pere ja suguvõsa ajalugu (de Groot 2009: 73-74; Ashton \& Hamilton 2007: 27).

Pereajalugu vahendab ajalooliste sündmuste tõlgendusi ja nende mõjutusi suguvõsas, sellel on märkimisväärne roll üksikisiku ajalooteadlikkuse sünnis. Ameerika Ühendriikide kodanike ajalooteadlikkust käsitlevas uurimuses, Roy Rosenzweigi ja David Theleni töös The Presence of the Past (Oleviku minevik, 1998) avaldub pereajaloo tähtsus kõikidel tasemetel. Pereajalugu oli üks populaarsemaid vaba aja harrastusi, see oli tähtsaim viis kogeda ühtekuuluvust minevikuga. Muuseumide kõrval peeti pereajalugu sugulaste isiklike kogemuste vormis kõige usaldusväärsemaks ajalooallikaks ${ }^{9}$ (Rosenzweig \& Thelen 1998: 21-22, 89-114). Soomes on olukord eelkirjeldatule üpris sarnane. Erinevus on vaid selles, et soomlased tunnevad ajaloo vastu suuremat huvi kui ameeriklased, ühtlasi usaldavad nad ka kooli ajalookursust ja teaduslikku kirjandust märgatavalt rohkem (Torsti 2012: 30, 40-44, 52-61).

Kuigi eriti väikestes piirkondades sulanduvad kodulugu ja pereajalugu omavahel, on tähele pandud, et koduloolased on tavaliselt mehed, pereajaloo tundjad ja vahendajad aga naised (Rosenzweig \& Thelen 1998: 29-31; vt ka Heimo 2010: 172-173). Pilvi Torsti soomlaste ajalooteadlikkust käsitleva uurimuse kohaselt vaatasid just naised koos lastega fotosid, jutustasid neile oma minevikust ja käisid koos lastega muuseumides. Mehed seevastu otsisid ajaloolist teavet meelsamini internetist ning vaatasid ajalooteemalisi telesaateid ja filme (Torsti 2012: 43-44). Naistele näis olevat tüüpilisem kujutada minevikusündmusi osana oma igapäevastest jutustustest, näiteks lapselapsele minevikust rääkides võrreldi läinud aegade kombeid või asju nüüdisaegsetega; mehed aga kommenteerisid ajaloolisi sündmusi stiilis "mis siis õieti juhtus" (Rantala 2012: 50). Mälestuste uurijate hinnangul võib siin põhjus seisneda asjaolus, et lapseeast peale pööratakse tütardele mälestusi rääkides tähelepanu pigem sotsiaalsetele suhetele ja tunnetele, poistele aga räägitakse enam faktidest (Fivush \& Haden 2005). 


\section{Kujuteldav pere, jutu-pere, peremälu}

Pere- ja sugulussidemeid kirjeldatakse üldiselt veresidemete kaudu. Soomlaste kõnekäänd "veri on paksem kui vesi" näitab, et sugulussuhteid peetakse teistest inimsuhetest tähtsamaks, ja viitab ühtlasi sellele, et just ühine genotüüp on see tegur, mis ühendab üksikud inimesed perekonnaks või suguvõsaks, ehkki peret ja suguvõsa võidakse käsitleda ka kui sotsiaalse ja kultuurilise võrgustikuna. ${ }^{10}$ Lisaks bioloogilisele (geneetilisele) sugulusele võidakse sugulust vaadelda ka sotsiaalsete rollidena, mis kultuuriti erinevad ja millest lähtuvalt inimesed ühiskonnas üksteise suhtes käituvad. Pereliikmeteks ja sugulasteks võidakse lugeda inimesi, keda peetakse lähedasteks, kuigi bioloogilist sidet nendega ei ole. Samas võib osa bioloogilistest sugulastest jääda väljapoole peret ja suguvõsa. Sugulus ei eelda füüsilist kohalolekut. Piisab isiku suguvõssa kuulumise teadvustamisest. Sel põhjusel võib peresid nimetada kujuteldavateks, nagu Benedict Anderson (1983) nimetab riiki kujuteldavaks: siin ei pea tingimata kõiki tundma, et olla kokkukuuluvusest teadlikud. (Vuorela 2002.) John Gillise järgi on kõigil kujutlustest, müütidest ja rituaalidest koosnev käsitus kujuteldavast ideaalperest (families we live by), samuti perest, kellega koos tahes või tahtmata tegelikult elatakse (families we live with) (Gillis 1996 tsit Smart 2007: 51; Smart 2011: 541). Raphael Samueli ja Paul Thompsoni toimetatud suulise ajaloo klassikasse kuuluva kogumiku The Myths We Live By (Mü̈̈did, mille järgi me elame, 1990) artiklid osutavad sellele, kui paljudel eri viisidel on pere ja pereliikmete rollidega seotud käsitlused kujunenud. Annette Kuhn (2002: 57) nimetab peret utoopiliseks, kuna perega seostatakse ootusi, millised need peaksid olema.

Astrid Erlli (2011: 56) järgi on peremälu (family memory) tähtsaim kommunikatiivse mälu (communicative memory) vorm, ta viitab Jan Assmanni käsitlusele kommunikatiivsest mälust kui tänapäeval toimuvast minevikumeenutamisest, mis on aldis kontekstilistele variatsioonidele (Erll 2011: 28-29; Assmann 2008). Peremälu puhul on tegemist põlvkondade vahelise mäluga (intergenerational memory), mis viitab nimelt põlvkonniti pere raames toimuvale mineviku-meenutamisele. ${ }^{11}$ Seega seob peremälu pere- ja suguvõsaliikmeid omavahel põlvkonniti (Halbwachs 1980 tsit Erll 2011: 17). Väidetakse, et perestruktuurist või suurusest sõltumata ühendavad eri põlvkondade peresid kõige enam peret või suguvõsa puudutavad jutustused, ühine ajalugu, samad mälestused. Pereliikmete mälestusi edasi rääkides kujundatakse ühismälu (shared memory), mida nimetatakse ka perelooks (Rosenthal 1998: 7 viide 9). Peremäludega määratletakse perekondlikud ja suguluspiirid: perre ja suguvõssa kuuluvad need, kellest räägitakse. Selles mõttes ei ole perelugu "veatu" (Smart 2007: 82-84; Meethan 2008). Teine paljukasutatud mõiste peremälu 
kõrval on järelmälu (postmemory) (nt Hirsch 1997). Esialgu viitas Marianne Hirsch selle mõistega eeskätt lastele edasi antud traumaatilistele mälestustele, näiteks sõja- ja holokaustimälestustele, tänapäeval kasutatakse mõistet ka laiemas tähenduses.

Folkloriste on huvitanud ennekõike jutustustena vahendatud perelood või perepärimus (vt nt Jaago 2002; Latvala 2005). Tavaliselt vahendatakse peremälu kujundavaid lugusid argipäevaolukordades igapäevase vestluse raames. Perepärimuslikule jutustamisele on omane, et järjest räägitakse palju lugusid, meenutades neid kas vaheldumisi või ühekaupa, nagu näiteks siis, kui vanavanem räägib oma järglastele enda lapsepõlvest. Kui mälestused on jutustajatele ühised, ei ole tingimata vaja neid isegi tervenisti korrata, vaid piisab viitest isikule või sündmusele: "Kas mäletad, kui vaar ...?” (Vuorinen 2001).

Eriti neile peredele, kelle liikmed elavad eri riikides, pakuvad perelood võimalusi luua ühtekuuluvusteadlikkust olukordades, kus võimalusi füüsilisteks kohtumisteks ei ole (Chamberlain \& Leydesdorff 2004). Nii kujundatakse lastes arusaam perest ja suguvõsast ka siis, kui nad kõikide sugulastega mitte kunagi ei kohtu. Väljarändaja sünnimaa, tema vanemate kodumaa ja need, kes sinna jäid, on väljarändajate mälestustes kesksel kohal. Väljarändaja mõtiskleb nende mälestuste üle kogu oma elu vältel, mõtestades neid taas ja taas uuesti. (Chamberlain \& Leydesdorff 2004: 228.) Alistair Thomson (2011) nimetabki väljarändajate mälestusi liikuvateks jutustusteks (moving stories): ümberasumisest pajatavad jutud käsitlevad liikumist ühest kohast teise; need lood on jätkuvalt liikvel (aktuaalsed); sageli on need teemad liikuvad (edasiarendatavad), sest äsjase immigrandi lugu on teistsugune kui kaua riigis elanud ümberasujal.

Soome Kirjanduse Selts korraldas 1997. aastal ulatusliku soomlaste perepärimuse kogumisvõistluse "Suvun suuri kertomus" (Suguvõsa suur lugu). Folklorist Pauliina Latvala uurimus Katse menneisyyteen (Vaade minevikku, 2005; vt sama kogu allikapublikatsiooni Latvala 2001) põhineb selle kogumisvõistluse käigus laekunud 720 kaastööl (kokku ligi 40000 lehekülge tekstimaterjali). Latvala (2005: 15) nimetab suguvõsa raames vahendatud mälestustest, lugudest jms moodustuvat käsitust suguvõsa pärimuslikuks ajalooks. Neile kirjalikele kaastöödele on omane suguvõsa- ja pereajaloo tõlgendamine rahvuse ajaloo osana: neis jutustati oma suguvõsa liikmete osalemisest sõjas ning kirjeldati põllumajandusliku murrangu, linnastumise ja koolihariduse mõju suguvõsas, samuti muutusi naiste staatuses. Paljudes kaastöödes jutustati suguvõsa kangetest naistest, sh ka Soome kodusõja ajal vapralt oma mehi kaitsnud naistest või naistest, kes tegid Teise maailmasõja ajal kodurindel meeste töid. Mälestused olid enamasti positiivsed edulood, seotud sugulastega, kellega jutustaja soovis samastuda. (Latvala 2005; vt ka Vuorinen 2001: 133, 136-139.) Latvala järgi 
suunavad Soomes üldlevinud genealoogia- ja suguvõsaliikumise harrastused tavasid, millest lähtudes inimesed oma suguvõsast räägivad: jutustamisel kasutatakse sugupuuskeemi ja sugulaste elulugudes mainitakse dokumentides leiduvaid andmeid. Genealoogia-käsiraamatutes soovitatud uurimisallikate ja uurimisjuhiste mõju on samuti suguvõsalugudes nähtav. Ehkki suguvõsa ja kodukandiga seonduvad kangelaslood paigutuvad sageli lähiminevikku, sisaldab kogumisvõistluse "Suvun suuri kertomus" ainestik ajaloolisi ja kohamuistendeid, millega rõhutatakse suguvõsa juurte sügavust ja kohateadlikkust. Osa kirjutajatest on valinud ilukirjandusest tuttava sõnastusstiili, püüdes võistlustööks luua konkreetsete tegelaskujudega tervikliku ja ehedat jutustust. Enda ja suguvõsa eluetappide tagasivaatav käsitlus on omakorda pärit autobiograafiatest ja mälestusteraamatutest. (Latvala 2005: 72-73, 76-78.) Folklorist Tiiu Jaago on kogumisvõistluse "Suvun suuri kertomus" materjali võrrelnud eestlaste suulise ja kirjaliku perepärimusega (Jaago 2002: 416; 2007).

Lisaks ühistele mälestustele ühendavad ja lahutavad pereliikmeid peresaladused. On avalikke saladusi, mida teavad kõik, kuid millest ei tavatseta rääkida, ja saladusi, mida teavad üksnes valitud pereliikmed. Peresaladusi uurinud Carol Smarti (2011) järgi on saladused sageli seotud haiguste, vaimse tervise probleemide, majanduslike raskuste, adoptsiooni, abieluväliste laste, raseduse katkestamiste ja kriminaalkaristustega. Soomes vaikitakse lisaks eespool mainitud teemadele ka enesetappudest ja vägivallategudest. Saladusi võidakse edasi pärida, ja isegi kui neist ka vaikitakse, võivad need avaldada mõju ühest põlvkonnast teise, olgu siis näiteks painajate-kummituste kaudu või eluvalikute tegemisel. Sageli kiidab osa pereliikmeid vaikimise heaks, soovides nii näiteks säästa järeltulevaid põlvi häbist või ebamugavatest teemadest. (Rosenthal 1998.) Sealjuures on ka ebameeldivaid või delikaatseid peremälestusi muudetud, sobitades neid paremini edasijutustamise aja konteksti, kohendades neid poliitiliselt korrektseks või lihtsalt meeldivamaks (Welzer 2005). Soomes salatakse ka sõjakogemusi. Pärast Soome kodusõda oli vaid sõja võitjatel, valgetel õigus sõjakogemusi avalikkuse ees meenutada (Peltonen 1996). Punaste poolel meenutati sõda avalikult vaid poliitiliselt aktiivsetes peredes. Tavaliselt siiski vaikiti, et pääseda häbist ja sotsiaalsest tõrjutusest (Westerlund 1999: 6-8; vt ka Heimo 2010: 135-136). Ka Teise maailmasõjaga seondub mahavaikitud kogemusi. Sõjaveteranid ja naiskodukaitsjad (lottad) on vaikimist põhjendanud ühest küljest sellega, et nad on selliselt toimides soovinud säästa oma perekonda, ja teisalt kultuurilise kogemusega, et sõjamälestustest ei ole üldse sobiv avalikult rääkida (vt nt Kinnunen 2006; Strandén 2010: 352, 358). Sõdurite psüühilisi probleeme, sõjavangide kohtlemist, sõjavägivalda ning Saksa sõduritega suhelnud naiste ja neist suhetest sündinud laste saatust on saadud uurima hakata alles 21 . sajandil. Teema avalik käsitlemine on toonud paljudele 
kergendust, ja näiteks Saksa sõdurite lapsed on võinud rajada isegi oma ühingu. Eestis avaldab lähiminevik sellest jutustamisele veelgi tugevamat mõju, ja ehkki paljud soovivad või tunnevad kohustust tuua läbielatu avalikkuse ette, on ka neid, kes eelistavad jätkuvalt vaikida (vt nt Kirss jt 2004; Kõresaar 2011).

\section{Pereajalugu: spontaanne ajalookirjutusprotsess ja osaluskultuur}

Igipõlistele küsimustele, kes me oleme ja kust me tuleme, ärgitab internet vastuseid otsima, sest vajalik teave võib olla vaid hiireklõpsu kaugusel (Srigley \& Zembryski 2009). Suguvõsauurijad mõistsid kohe 1990. aastate alguses, milliseid võimalusi pakub internet genealoogiale. Sotsiaalmeedia läbimurre 2000. aastatel on innustanud inimesi pereajalooga tegelema, arhiividokumentide, registrite ja ajalehtede ulatuslik digitaliseerimine inspireeris neid läbi vaatama oma pere ajaloo seisukohast. Tänapäeval on internetis ohtralt saadaval ka genealoogilisi programme, pereajaloo uurimise käsiraamatuid ning võrguteenuseid suguvõsauurijate tarbeks. Informatsiooni otsijatest ja kasutajatest said ühtlasi ka selle loojad ja jagajad.

Kirjeldatud muutust pere- ja suguvõsaajaloo uurimises võib vaadelda kui nähtust, mida David Thelen nimetab participatory historical culture (Thelen 1998: 190) - see hõlmab inimeste spontaanset, ühistele kogemustele ja olnu mõtestamisele rajanevat järjekestvat ajalookäsitluse loomet. Arvestades internetikasutuse aktiivsust, on see lähedane ka Henry Jenkinsi (Jenkins jt 2006) kontseptsioonile osaluskultuurist (participatory culture), mille all peetakse silmas internetikogukondade koostöös loodavaid aheltekste vm esitusvorme. Osaluskultuuris tulevad esile erinevad rühmad, millega seoses hajuvad nt piirid professionaalide ja amatööride vahel. See ilmneb internetis suurepäraselt: siin leidub lõputult näiteid, kuidas inimesed ja ühingud loovad ja vahendavad oma tarbeks minevikuga seonduvat teavet.

Suguvõsauurijad ja ümberasujad on ühed tähelepanuväärsemad interneti kasutajarühmad. Esmalt tulevad ümberasujad internetti teavet otsima, järgmisel etapil hakkavad nad ühendust pidama maailma eri osades asuvate sugulaste ja kaasmaalastega ning kolmandal etapil asuvad kasutama internetti selleks, et tutvuda oma ajalooga (Silberman \& Purser 2012: 22). Olen oma praeguse uurimuse tarbeks jälginud aktiivselt paljusid Facebookis tegutsevaid kogukondi ning veebilehti meenutamise ja ajaloo-alase tegevuse seisukohast. Näiteks Facebooki kogukonda Finnish genealogy kuulub umbes 1800 liiget peamiselt Ameerika Ühendriikidest ja Soomest (01.10.2013). Mehi ja naisi on rühmas peaaegu võrdselt. Rühma eesmärk on pakkuda oma liikmetele keskkonda, 
kus saaks vestelda suguvõsajuurtest, ümberasumisest ja DNA-st ${ }^{12}$. Facebooki leheküljel vahetavad kogukonna liikmed teavet ja kogemusi, nad edastavad üksteisele perelugusid ja fotosid, aga ka romaane, filme, uurimusi ja arhiivimaterjale.

Eelmisel sügisel mõtiskles üks Soome päritolu naine selle üle, miks tema vanaema kolis 20. sajandi alguses Ameerika Ühendriikidesse, ja küsis Finnish genealogy veebilehel, milline majanduslik olukord valitses tol ajal Soomes. Kas ehk nälg sundis tema vanaema Ühendriikidesse minema? Küsija sai mõne päeva jooksul kümneid vastuseid. Inimesed jutustasid perekeskseid mälestusi oma vanavanemate ümberasumisest Ameerika Ühendriikidesse ja selle põhjustest, soovitasid teemat käsitlevaid veebilehti, romaane, uurimusi ja arhiive. Teine näide sama kogukonna veebilehelt on seotud soomlaste kohvijoomistavaga. Postituste ahela lükkas käima umbes leheküljepikkune iseseisva failina esitatud lugu, kus eespool mainitud naine meenutas kohvijoomist koos soomlasest vanaemaga. Meenutusele reageeriti viivitamatult ja paarkümmend inimest saatis oma mälestusi soomlaste kohvijoomistest, kogetud kas Ühendriikides või külaskäikudelt Soome. Mälestustes käsitleti kohvijoomisega seonduvat kombestikku, võrreldi eri rahvuste tavasid ja meenutati soomlastest vanavanematega veedetud kohvihetki. Selles vestluses osalesin ka ise, saates lingi ajalehes Arctic Anthropology avaldatud Fredric M. Robertsi artiklile "The Finnish Coffee Ceremony and Notions of Self" (Soome kohvitseremoonia ja arusaam endast, 1989). Minu saadetud link ärgitas korra juba vaibunud vestlust taasalustama ja üle kahekümne inimese jätkas mõttevahetust samal teemal.

Nagu eespool esitatud näited osutavad, sünnib suurim osa minevikuga seonduvatest tõlgendustest jätkuvalt spontaanselt, kui selleks tekib sobiv võimalus. See tõlgendusprotsess on mõeldud oma tarbeks ja toimub samalaadsete kogukondade vahel. Samuel Schrager (2004: 284-285) kirjeldab meenutusi kui järjekestvaid vestlusi; need on omalaadsed protsessid, mis on alanud varem ja jätkuvad iga kord, kui mõni vestluses osaleja pakub sellesse oma lisa, hinnates, seletades ja esitades oma nägemusi ning kasutades mitmesuguseid retoorilisi vahendeid, kinnitamaks muude tõlgenduste pädevust. Lisaks valib ta pidevalt võimalusi, mil viisil ta oma käsituse esitab, millisest vaatenurgast lähtub ja mida jätab rääkimata.

Neil Silberman ja Margaret Purser (2012: 16-17), kes on uurinud kultuuripärandi uusi vorme sotsiaalmeedias, nimetavad eelkirjeldatud protsessi esitusmäluks (performative memory). Iga toimuv keskustelu on esitus, millel pole üheselt määratletavat algust ega lõppu. Keskustelu võib hääbuda, et puhkeda mõnel teisel hetkel taas. Nende esituste eesmärk on leida seoseid oleviku ja mineviku vahel ning arutleda võimu ja autoriteedi üle. Tänapäeval toimuvad need esitused üha sagedamini internetis. Mälu-uurijad kasutavad sama mõistet, 
rõhutades digitaalse mälu esituslikku loomust. Internetis avaldatavad mälestused on tavaliselt läbi mõeldud, pidades silmas kindlat sihtrühma.

Lisaks Austraalia-soomlaste kogukonnale leidub Facebookis terve hulk samalaadseid soomlastele suunatud kogukondi eri linnades. Need kogukonnad esindavad peamiselt esimese etapi internetikasutajaid. Need, kes alles kavandavad Austraaliasse reisimist või on sinna saabunud lähiminevikus, küsivad abi praktiliste argiprobleemide lahendamiseks ja Austraalias juba kauem elanud inimesed annavad neile abivalmilt nõu. Teise tüüpilise näite pakub Facebooki kogukond Bli Bli on Maroochy Historical Society Inc. Artikli kirjutamise ajal kuulus sellesse kogukonda 134 liiget (30.09.2013). Bli Bli on Maroochy Historical Society Inc. on Austraalia läänerannikul asuva väikese paikkonna kodulooühing. Ühingu juhataja ja paljud selle aktiivsed liikmed on 19. sajandi lõpus sinna piirkonda tulnud Austraalia esimeste soomlaste ühenduse Finbury järeltulijad. Veebilehel avaldatakse piirkonna ajaloo ja inimestega seonduvaid uudiseid, fotosid ja materjale ning ühtlasi on seal ka andmeid soomlastest ümberasujate ajaloost Austraalias.

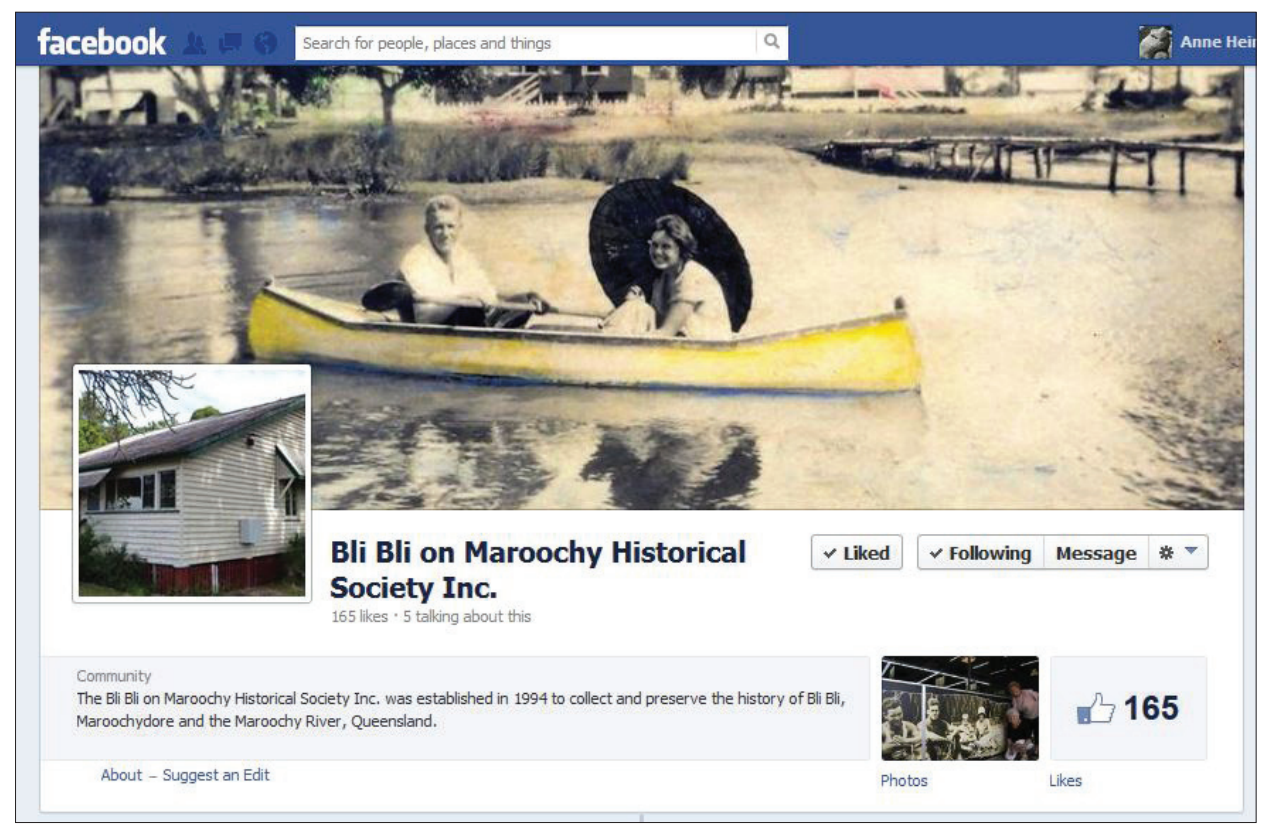

Ühingu Bli Bli on Maroochy Historical Society Inc Facebooki avalehel on pilt selle ühingu esimehe Soomes sündinud vanematest, nautimas suvepäeva 1920. aastatel (31.01.2014). 


\section{Austraalia - ümberasujate maa}

Viimase saja aasta jooksul on välismaale ümber asunud hinnanguliselt üle miljoni soomlase. Soome Migratsiooniinstituudi statistika kohaselt on põhiosa emigratsioonivoolust suundunud Põhja-Ameerikasse (üle 400000 inimese, kellest põhiosa asus ümber enne Esimest maailmasõda) ja Rootsi (üle 600000 inimese, kellest põhiosa asus ümber pärast Teist maailmasõda). Nendega võrreldes on ümberasumine Austraaliasse olnud väike. Aastatel 1860-2010 on Soomest Austraaliasse emigreerunud vaid 24000 soomlast. (http://www. migrationinstitute.fi/stat/Siirtolaisuus_kartta_1860-2010.jpg.) Austraalia 23 miljonist elanikust üle 6 miljoni moodustavad ümberasujad, kes on sündinud väljaspool Austraaliat. Teiste rahvusrühmadega võrreldes ${ }^{13}$ on soomlastest ümberasujate arv väga väike. Soome päritolu inimeste arv on hinnanguliselt alla 30000 ja nendest vaid 7900 on sündinud Soomes (http://www.immi.gov. au/media/publications/statistics/comm-summ/textversion/finland.htm).

Esimesed soomlased Austraalias olid meremehed, kes läksid 1850. ja 1860. aastatel Victoria ja New South Walesi kullaväljadele õnne otsima. Esimene püsiv soomlaste kogukond loodi 19. sajandi lõpus Nambouri suhkruroopiirkonnas Queenslandis. 20. sajandi alguses elas Finburys 70 soomlast. Esimene tõeline sisserändelaine Austraaliasse jääb 1920. aastatesse, kui Ameerika Ühendriigid asusid immigratsiooni piirama. Siis läks Austraaliasse ohtralt vallalisi mehi Pohjanmaalt. Sageli viibisid nad seal mõne aasta ja kui olid teeninud piisavalt raha oma talu ostmiseks, tulid tagasi Soome. Teine ümberasumislaine oli 1950. ja 1960. aastate vahetusel, kui Austraaliasse läks tööd otsima ka palju perekonnainimesi. (Koivukangas 1998.) Austraalia riik vajas sel ajal töökäsi ja toetas seepärast immigratsiooni, abistades majanduslikult riigile sobivaks peetud sisserändajaid, tasudes osa nende ümberasumiskuludest. Immigrandid omalt poolt lubasid vastutasuks töötada vähemalt kaks aastat Austraalias. (Jupp 2007.)

Austraalia järgis kaua diskrimineerivat immigratsioonipoliitikat. See oli niinimetatud White Australia Policy, kus Austraalia soosis teatud riikide ümberasujaid, näiteks põhjaeurooplasi (Jupp 2007). Pööre toimus aastal 1973, mil riigi ametlikuks liiniks sai mitmekultuurilisus. Muutuse tulemusel asutati 1986. aastal Adelaide'is riigi (ja ühtlasi maailma) esimene ümberasujate muuseum. Paljud muuseumid hakkasid oma näitusekavadesse võtma migratsiooniteemat ja tutvustama teisi kultuure koostöös sisserändajate kogukondadega, teostades niiviisi uut riiklikku narratiivi Austraaliast kui immigrantide riigist (Nation of Immigrants). (Henrich 2013.) Muutus ilmneb ka viisides, kuidas praegu ümberasujate panust esile tõstetakse, tuues näiteks selliseid riiklikult olulisi hankeid nagu Austraalia ajaloo 


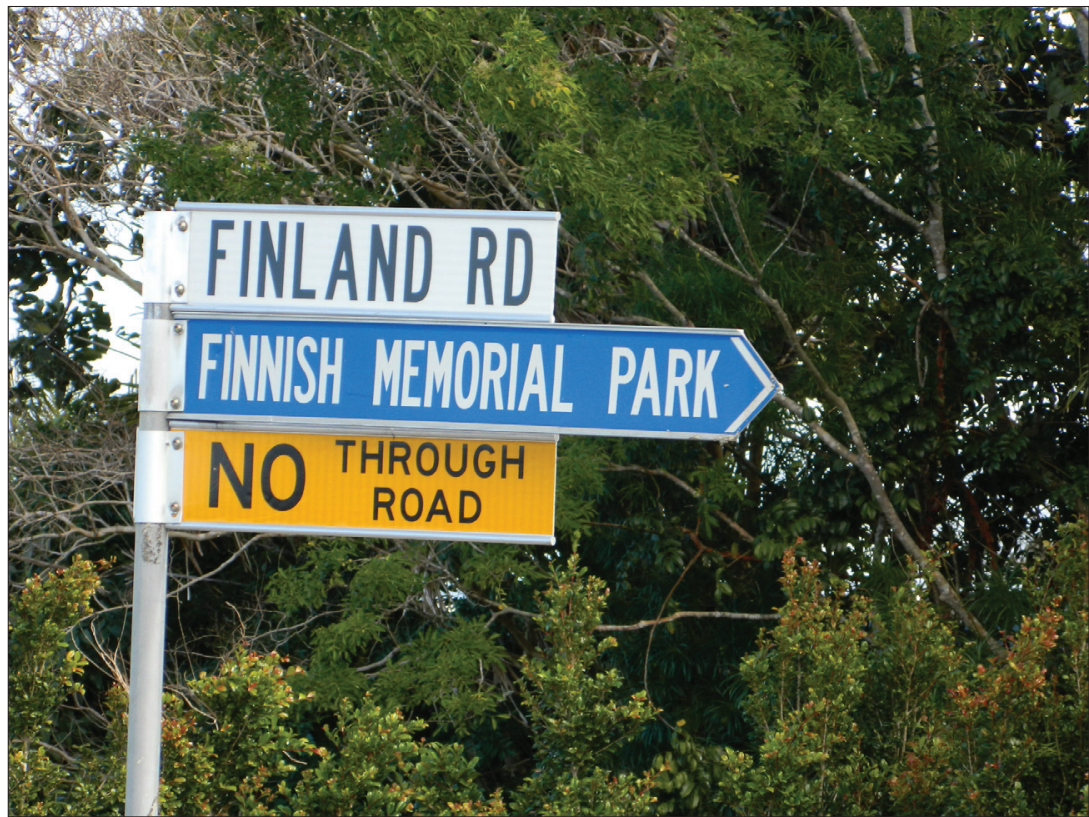

Teeviit Nambouri Bli Blis meenutab sealseid endisaegseid soomlastest ümberasujaid (30.09.2013).

suurim elektrifitseerimishange Snowy Mountain Scheme (vt nt http://www. migrationheritage.nsw.gov.au/exhibition/newaustralia/building-the-snowy/; Ashton et al. 2012: 22-26).

Erinevalt paljudest teistest etnilistest rühmadest ei ole soomlased siiski kuigi innukalt asunud tutvustama oma ühiskonna pärimust. ${ }^{14}$ Soomlaste migratsiooni on käsitletud kümnetes mälestustes ja ilukirjanduslikes teostes, kuid mõnesid erandeid arvestamata on need reeglina omal kulul avaldatud materjalid äratanud vähe tähelepanu. (Punta-Saastamoinen 2010.) Nambouris kiirtee Finland Road'i ääres asuvasse soome mälestusparki (Finnish Memorial Park) püstitati 1997. aastal mälestusmärk soomlastest immigrantidele. ${ }^{15}$

On jäädvustatud ka üksikisikute mälestust, andes nende nime mõnele tänavale või pargile. Näiteks Kanervo Road Põhja-Queenslandis meenutab selles piirkonnas kunagi tubakat kasvatanud Kanervo perekonda. Nestori Karhula (1893-1971) oli üks tuntumaid poliitilise mõjujõuga soomlasi Austraalias. Karhula kodulinnaosas Brisbane Eight Mile Plains'is on tema auks nimetatud park. Arvukad mälestustega tegelevad organisatsioonid, arhiivid ja muuseumid, samuti eraviisiliste projektide algatajad koguvad aktiivselt pereajalugu ja väljarändajate mälestusi. Näib, et mälestused on osutunud ümberasujatele 
igal pool maailmas eriti tähtsaks. (Vt nt Ashton \& Hamilton 2007; Guelke \& Timothy 2008; Marselis 2011; Henrich 2013.) Migratsiooniga seotud arhiivid ühendavad eri riike, ent on samas olulised ka iga üksiku riigi rahvusliku ajaloo seisukohast (Creet 2011: 3). Austraalia on sellesse töösse panustanud rohkem kui Soome ja paljud teisted riigid. Lisaks mälestustega tegelevatele organisatsioonidele annavad sellest silmnähtavat tunnistust alates 1990. aastate lõpust Austraalia eri osadesse ümberasujate auks püstitatud Welcome Wall või Tribute Wall tüüpi mälestusmärgid. Need Ameerika Ühendriikide Ellis Islandist ajendatud mälestusmärgid on tavaliselt muuseumidega seotud seinad, millele võib tasu eest graveerida ümberasuja nime ja muid andmeid, näiteks ümberasumise aasta või päritoluriigi. Kõne alla võib tulla ka seinale kinnitatav plaat, millele on graveeritud nimetatud teave. Nii on tehtud Austraalia suurimas ja vanimas ümberasujate vastuvõtukeskuses Bonegillas asuvas muuseumis Block 19, Bonegilla Migrant Experience.

Sydneys asuva Austraalia riikliku meremuuseumi (Australian National Maritime Museum - ANMM) Welcome Wall on neist suurim. Seal lisandub füüsilisele mälestusseinale elektrooniline andmebaas, kuhu võib salvestada

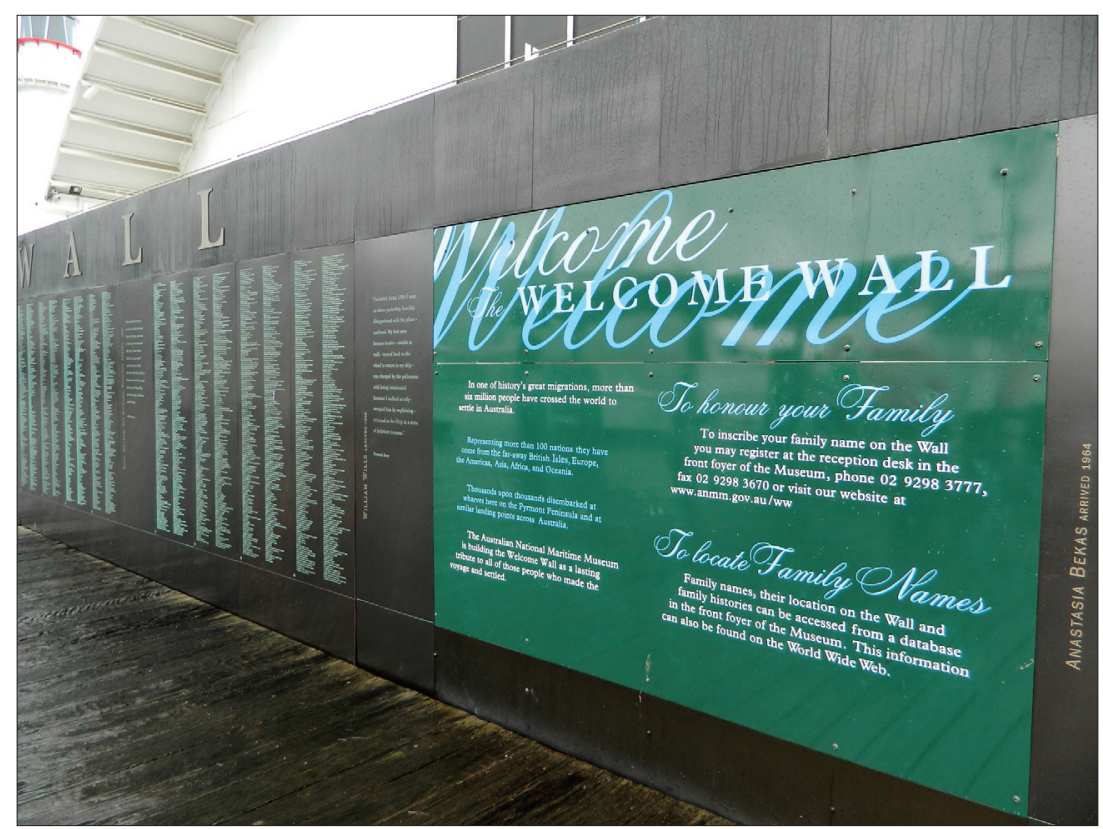

Memoriaalsein - Welcome Wall Austraalia riiklikus meremuuseumis Sydneys. Anne Heimo foto 2012. 
lisaks ümberasuja isikuandmetele ka muud temaga seonduvat teavet ja tema minibiograafia. Randi Marselis (2011) nimetab neid digitaalseteks mälestusmärkideks (digital monuments), kuna nende abil hoitakse au sees ümberasujate mälestust. Kevin Fewster (tsit Henrich, ilmumas) seevastu ennustab, et tulevikus muutuvad need "tõelisteks küberkalmistuteks" (veritable cyber cemetery).

Austraalia riikliku meremuuseumi Welcome Wall asutati 1999. aastal ja praeguseks (01.10.2013) on memoriaalseina graveeritud 206 riigist pärineva rohkem kui 25000 ümberasuja nimi, kellest 79 (37 naist, 42 meest) on soomlased. Iga ümberasuja kohta leidub sissekanne avalikus elektroonilises andmebaasis (http://welcomewall.anmm.gov.au/). Nagu eelpool öeldud, võib andmebaasi märgitud olla lisaks ümberasuja nimele tema sünniaeg, amet ja teave riiki saabumise kohta (millega, kuhu ja millal). Andmebaasi võib lisada ka lühikese, umbes 50-sõnalise lühibiograafia. Paljudes biograafiates kõneldakse ümberasuja saabumisest, töökohtadest ja perekondlikest suhetest, nagu järgmises näites:

Tü̈̈piline poissmehest sisserändaja elu: saabudes vähene, kuid aja jooksul omandatud inglise keele oskus. Alustanud terasetehasest, jätkates töölisena mitmetel ehitustöödel, Mount Isa kaevandustes, Qld'is [Queensland] suhkruroo lõikurina, kuni läks tagasi Wollongongi elama. Abiellus ja alustas 1971. aastal omaenda äriga Sunset Blinds, mis tegutseb tänaseni. Mitte kunagi ei olnud ta töötu.

Selle 1959. aastal Austraaliasse rännanud mehe lugu on tüüpiline. Ta on sündinud 1930. aastatel ja läheb poissmehena Austraaliasse tööd otsima. Tema keeleoskus on algul nõrk, kuid paraneb aegamööda. Ta rändab riigis tööd otsides ringi ja töötab, nii nagu paljud teisedki soomlased ehitustel, kaevandustes ja suhkrurookasvandustes. Lõpuks jõuab ta välja ühte paljudest soomlaste keskustest, leiab endale (soomlannast) naise ja asutab eduka ettevõtte, ja nagu ligi pooled Austraaliasse väljarännanutest, elab ta praegu Soomes. Naiste jutustused on sageli lühemad või lausa kordavad oma abikaasa lugu. Ka järgmise, oletatavasti abielupaari laste kirja pandud loo sisu on tüüpiline:

Külmas Põhja-Soomes nägi Korpis sooja maa reklaami. Aasta hiljem olid nad Sydneys. Viiskümmend aastat hiljem oli "uutel” austraallastel kaks austraalia last. [Naine] õppis inglise keelt naiste nädalakoolis. [Mees] aitas ehitada ooperimaja ja ehitas sauna garaaži.

Teise näite toon kavandamisjärgus olevast projektist "Immigration Place" (Sisserände paik), mille eesmärk on "austada kunagisi, praeguseid ja tulevasi Austraaliasse ümberasujaid” ja püstitada nendele Canberrasse mälestusmärk. Projekti veebilehel avaldatakse ümberasujate mälestusi. Seni on veebilehel 


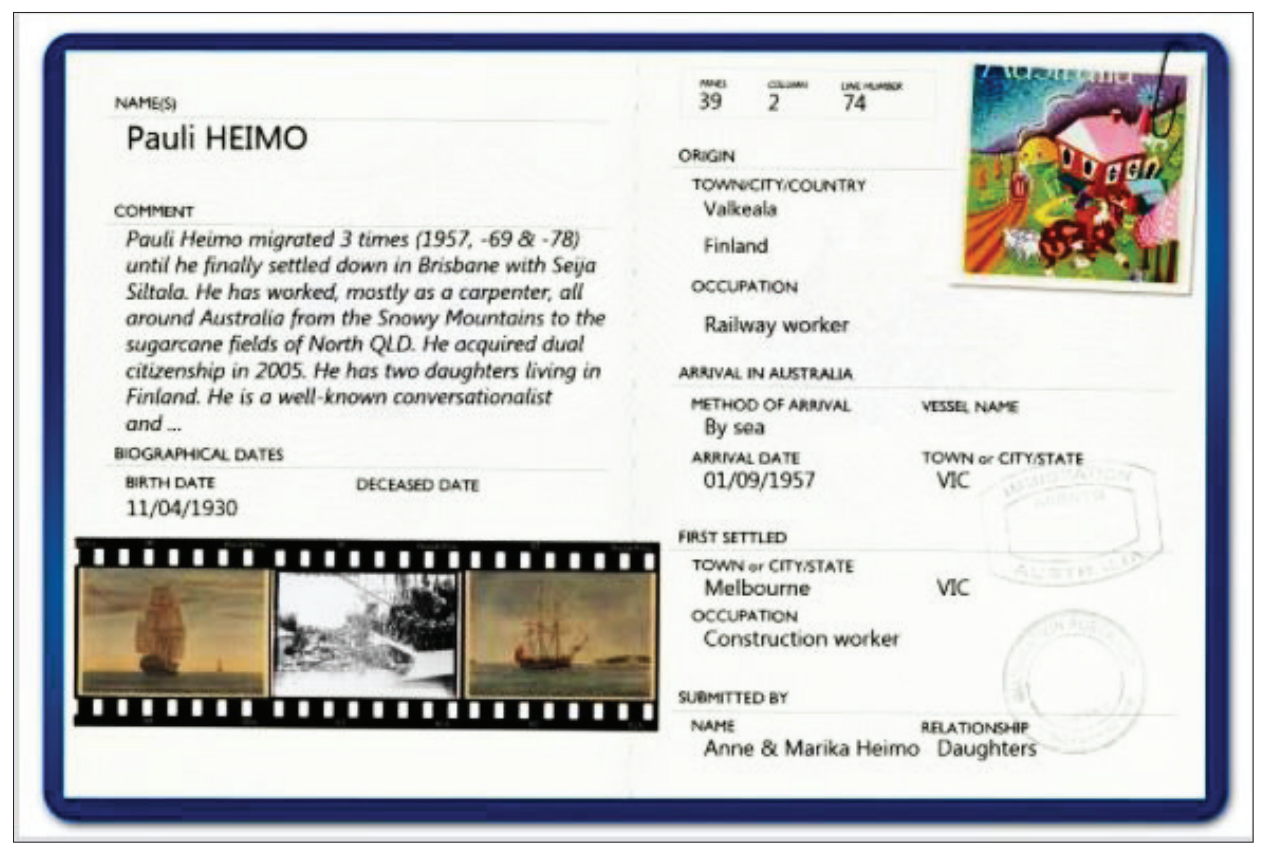

Minu isa Pauli Heimo lühibiograafia (14.10.2013).

avaldatud 1657 jutustust 147 riiki esindavatelt inimestelt (01.10.2013). Neist kümme lugu (2 naist ja 8 meest) on kirjutanud kas soomlasest ümberasuja ise või tema järeltulijad. Mälestustest (mille pikkuseks võib olla kuni 4500 tähemärki) kaks on kirjutanud ümberasuja ise, ülejäänud kaheksa on kirjutanud laps või lapselaps. Kirjutades järgitakse enamasti veebilehel antud juhiseid täpselt: kes, mis, millal, kuhu ja miks (http://www.immigrationplace.com.au/immigrationplace/w4/i1040467/).

Meenutused ei korda sündmusi kunagi täpselt, sest teatud asju rõhutatakse, teatud asjadest ei räägita, et jutustus oleks huvipakkuvam ja mõistetavam. Nagu igasuguste jutustuste puhul, kujundavad ka Austraalia-soomlaste lugusid antud juhiste kõrval väljakujunenud jutumudelid. Näiteks Austraalia-soomlaste jutustustes kujutab vaid mõni üksik end välissoomlasena või riigiülesesse või mitmekultuurilisse perre kuuluvana, ehkki Austraalia-soomlaste seas leidub ka neid. Osalemis- ja kirjutamiskutset on peetud kehtivaks nimelt vanade ümberasujate kohta. ${ }^{16}$ Paljud määratlevad end kui “tüüpilist” ümberasujat, kes lahkus Soomest tööpuuduse või halva kliima tõttu või läks lihtsalt seiklema. Paljud nimetavad eraldi, et Austraalias on lastele paremad võimalused kui Soomes. Ehkki soomlased on teinud enamasti lihttööd näiteks puusepa 


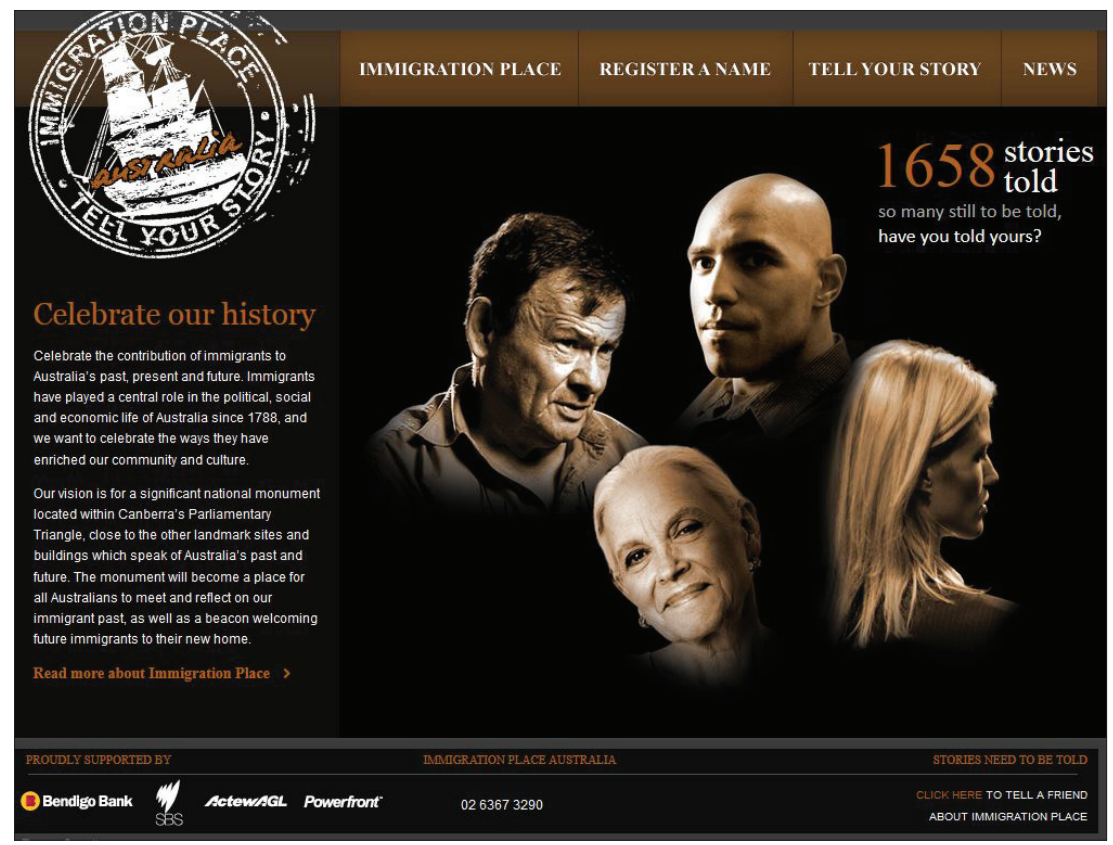

Projekti "Immigration Place" esileht veebis (14.10.2013).

või kaevurina, on üle poole sissekannetest teinud ettevõtjad ja ametnikud. Mitte keegi ei räägi sellistest ümberasujate probleemidest nagu tööpuudus, keeleoskamatus, koduigatsus või alkoholilembus - need on nimelt peamised põhjused, miks soomlased on Austraaliast Soome tagasi pöördunud. Ilmneb, et need probleemid on soomlaste seas olnud sedavõrd tavalised, et umbkaudu pooled Austraaliasse läinutest on tulnud Soome tagasi ${ }^{17}$ (Koivukangas 1998). Hoolimata sellest, et peaaegu kõik nimetavad uue kodumaa eeliseid, märgivad nad siiski, kui tähtis on neile Soome. Paljudele tähendab soomlus sauna või kontakte Soomes elavate sugulastega.

Paljud jutustused on edulood, mida võiks nimetada "kerjusest rikkuriks", kus ümberasuja suudab esialgsetest raskustest (nt keeleoskamatus, kliima) hoolimata võtta Austraalia oma uueks kodumaaks, teisisõnu adapteeruda. Selle saavutuse eest peab tubli immigrant olema tänulik. Lisaks oodatakse temalt, et ta tubli emigrandi kombel igatseb oma vana kodumaa järele ja tunneb nostalgiat, kuid mitte liigselt (vrd Jaago 2011; vt ka Chamberlain \& Leydesdorff 2004: 229). Ma ei osanud eeldada, et soomlastest ümberasujate jutustused langeksid kokku Eureka Henrichi (ilmumas) käsitletud Welcome Walli mikroperelugudega (micro family histories), nagu ta neid lühibiograafiaid nimetab. 
Ka tema vaadeldud näidetes on eri riikidest ümberasujate jutustused edulood, milles väljendatakse tänulikkust Austraalia pakutud võimalustele.

Eelkirjeldatud jutustused põhinevad nii isiklikel kui ka eelmiste põlvede mälestustel, kuid on vormitud avalikeks ümberasumisest kõnelevateks jutustusteks, mis on kooskõlas Austraalia rahvusliku narratiivi ja kodustamispüüetega (vt Henrich 2012; 2013). Ühtlasi loovad need püsiva sideme ümberasuja ja tema uue kodumaa vahel.

\section{Lõpetuseks}

Infotehnoloogia ja internet on pöördeliselt avardanud võimalusi olla üksteisega ühenduses ajast ja kohast sõltumata. Eeskätt ümberasujate seisukohalt on muutus olnud tähelepanuväärne. Arvukad mälestustega tegelevad organisatsioonid pakuvad kasutajatele võimalusi osaleda minevikku käsitleva teabe loomises ja otsivad innukalt uusi võimalusi, kuidas infotehnoloogiat oma tegevuses ära kasutada. Ometi õnnestub neil harva kaasata inimesi samasugusesse vastastikusesse koostöösse kui ühiseid kogemusi või huvisid jagavate inimeste omal algatusel loodud ja spontaanselt sündinud veebilehed (vt nt Affleck \& Kvan 2008). Eriti just sellistele väikestele ja hajusalt paiknevatele kogukondadele, nagu siin artiklis käsitletud Austraalia-soomlased, pakub internet uusi võimalusi ajaloo-alaseks tegevuseks, mis on ka väljapool kogukonda kättesaadav.

Käsitletud näited illustreerivad sotsiaalajaloolase Raphael Samueli (1994) käsitlust ajaloost kui inimeste loodud teabest, kusjuures loometegevuses osalevad kõik, mitte ainult professionaalsed ajaloolased. Selles protsessis on kõik minevikuga seonduva teabe vahendamise viisid võrdväärsed ja mineviku tõlgendamises osalevad kõik. Teisisõnu võib ajaloo esitajana tegutseda kes tahes meie hulgast, olenemata haridusest või elukutsest, ja kogutud mälestusi võib esitada ükskõik millises vormis. Sellest vaatenurgast lähtudes on näiteks iga suuline või kirjalik mälestus samaväärne akadeemilises ajaloouurimuses avaldatud kirjeldusega samast sündmusest. Protsess kestab lakkamatult, sest vajadus uue teabe järele nõuab uusi minevikutõlgendusi (Kalela 2012; 2013: 105). Koos internetiga on teostunud Raphael Samueli mõte ühiskonna kõigist liikmetest kui ajalookirjutuses osalevatest tegelastest viisil, mida ta vaevalt ette näha suutis. Inimesed on alati osalenud ajaloo ühiskondlikus loomisprotsessis (Heimo 2010). See aga, kuidas internet selle protsessi nähtavaks muudab, on uus.

Samas on interneti kasutamisega kaasnenud muutus hägustanud professionaalide ja amatööride vahelist piiri. Ehkki nn tavalised inimesed on alati loonud minevikuga seotud teavet oma tarbeks, ei ole neil kunagi varem olnud selliseid võimalusi tegutseda kõrvuti ajaloovaldkonna professionaalidega nagu 
praegu. See tähendab ühtlasi, et niisugused jaotused nagu privaatne ja avalik mälu või ametlik ja mitteametlik kultuuripärand tuleb uutest seisukohtadest lähtudes üle vaadata. Internet ja eriti sotsiaalmeedia on muutnud varasemaid käsitusi kultuuripärandist. (Silberman \& Purser 2012.) Kultuuripärand ei koosne enam üksnes mälu- ja muuseumiprofessionaalide valitud esemetest, mälestusmärkidest või ajaloolistest kohtadest. Nagu Elisa Giaccardi (2012: 1-2) tõdeb, luuakse “uut" kultuuripärandit mälestuste ja identiteedi kujundamise kaudu ühises ja korduvas tegevuses, lähtudes ühise mineviku materiaalsetest ja endiselu jälgedest. Samuti muutub mälestustega tegelevate organisatsioonide roll kultuuripärandi hoidjana. Edaspidi peaksid need tegema senisest tihedamat koostööd inimestega, kes tegelevad ajalooteemadega omaalgatuslikult ja enda tarbeks. Või kas peaksid, kuigi selliselt loodud ajalooalane teave on ajaloo käsitlusviise demokratiseerinud? Kas ka edaspidi jäävad mineviku kõige olulisemateks esitajateks institutsioonid, muuseumid, kooliharidus ja teadus, nagu on oletanud näiteks Paul Ashton ja Paula Hamilton (2007: 7-8)? Muutus ei kaota küsimust mälu, ajaloo ja kultuuripärandi poliitikast. Jätkuvalt tuleb küsida, kes mäletab, kuidas mäletab ja mida mäletatakse? Kelle ajalugu peetakse meeles? Kelle mälestustest sünnib kultuuripärand?

\section{Tänuavaldus}

Artikli aluseks olevat uurimust ja artikli koostamist on toetanud Soome Akadeemia projekt "Oma koht? Perepärimuse kujunemine globaalses kontekstis" (250307; 2011-2013) ja COST-meede "In Search of Transcultural Memory in Europe" (Otsides kultuuride vahelist mälu Euroopas, IS1203).

\section{Kommentaarid}

1 Rahvusvahelistes uurimustes kasutatav mõiste family history osutab nii pere- kui ka suguvõsaajaloole. Artiklis kasutatakse selguse mõttes mõistet pereajalugu (perhehistoria). Pereajalugu tähendab selles artiklis eeskätt inimeste spontaanset perega seonduva ajaloo uurimist, mitte teaduslikku pereuurimust. Rahvusvahelistes uurimustes kuulub pereajalugu ennekõike sotsiaal- ja rahvastikuajaloo uurimisalale, mille raames käsitletakse perestruktuure ja muid ühiskonna muutusi kujundavaid tegureid. 1980. aastatest alates on pereajalugu hakanud uurima ka pärimusliku ajaloo ja mälu-uurijad (Latvala 2005: 38; Srigley \& Zembryski 2009).

2 Juba 1999. aastal oli Soomes hinnanguliselt üle 900 suguvõsaühingu (Spoof 1999).

3 Soomes ei ole sari olnud nii menukas kui Ameerika Ühendriikides ja Inglismaal, kus see on äratanud ka uurijate tähelepanu (vt nt de Groot 2009; Kramer 2011a).

4 Näiteks BBC-l on oma pereajaloole pühendatud veebileht (http://www.bbc.co.uk/ history/0/23493076). 
5 Hargmaiseks pereks (transnational family) nimetatakse perekonda, mille liikmed elavad vähemasti osaliselt lahus, kuid perekondlikke suhteid ja sugulasvõrgustikku säilitatakse üle riigipiiri(de) (Bryceson \& Vuorela 2002: 3).

${ }_{6}$ Artikkel on edasiarendus 2013. aastal ilmunud ingliskeelsest artiklist "Online Memories of Migration" (Heimo 2013).

7 Veebilehele on antud 664255 positiivset hinnangut (12.09.2013).

8 See siiski ei tähenda, nagu oleks vähenenud perekonna või lähedaste inimsuhete tähtsus (Smart 2007: 10-16).

9 Muuseume hinnati usaldusväärseks seal eksponeeritavate autentsete esemete tõttu. Rosenzweigi \& Theleni (1998: 21-22, 89-114) kohaselt võib muuseumide hindamise taustal näha sama tegurit, mis ilmneb sugulaste isiklike kogemuste hindamisel. Mõlemal juhul tekitavad usaldust just nimelt vahetud kogemused.

10 Üldise määratluse kohaselt on samasse suguvõssa kuuluvatel isikutel ühiseid esivanemaid või on nad suguvõsa liikmeks saanud abielu või adoptsiooni kaudu. Perekonna moodustavad koos elavad abielus või vabaabielus või oma lähisuhte registreerinud isikud ja nende lapsed, üks või teine vanematest oma lastega ning abikaasad ja elukaaslased ning lähisuhte registreerinud isikud, kellel ei ole lapsi.

${ }^{11}$ Mõiste 'transgenerational memory' viitab põlvkondi ühendavatele mälestustele, mida vahendatakse ajalookultuuri eri vormide abil ning kus meenutusprotsess hõlmab laiemat ringi kui pere, toimudes näiteks rahvusvahelisel tasandil.

${ }^{12}$ DNA-uuringutega seotud testid on pereajaloolaste seas muutunud populaarseks. Lisaks pärilikke haigusi puudutavatele andmetele sisaldavad need ka andmeid testitu esivanemate kohta. See võimaldab tellida teateid geneetiliste sugulaste kohta, kasutades näiteks ärieesmärkidel tegutseva ettevõtte Family Tree DNA (http://www. familytreedna.com/) teenuseid. (Vt lähemalt nt Nash 2008: 219-263.)

${ }^{13}$ Näiteks britte elab Austraalias üle miljoni, uus-meremaalasi üle 500 000, hiinlasi üle 300000 ja itaallasi üle 200000 (http://www.immi.gov.au/media/statistics/).

${ }^{14}$ Leedu ja läti kogukonnad olid esimesed etnilised rühmad, kes asusid tutvustama oma kultuuri Austraalias ja rajasid esimesed oma muuseumid. Leedulaste kogukonna muuseum avati 1967. aastal, lätlaste ja eestlaste oma 1970. aastail (Henrich 2012: 56).

${ }^{15}$ Australian Centre for Public History, University of Technology, Sydney kaardistas aastatel 2004-2008 mittesõjalisi mälestusmärke. Andmebaasi kuuluvast 378 mälestusmärgist on ümberasujatele pühendatud mälestusmärke 12. Finnish Memorial Parki mälestusmärki nende hulgas ei ole (Ashton jt 2012: 4-7; http://www.acph.nicheit. com.au/).

${ }^{16}$ Welcome Wallil on vaid üks kirje 2000. aastatel Austraaliasse ümberasunult ja üks kirje 1990. aastatel ümberasunult, ülejäänud on riiki tulnud 1920.-1970. aastatel. Immigration Place'i mälestused pärinevad aastail 1899-1981 ümberasunutelt.

17 Teistest riikidest Soome tagasipöördumine on olnud märgatavalt väiksem kui Austraaliast (Koivukangas 1998).

\section{Veebilehed}

Albury City, Sharing Bonegilla Stories, Migrant memory database: http://www. bonegilla.com.au/collection/memories/images/Bonegilla_Memories_Database.pdf 9. jaanuar 2014 . 
Australian Centre for Public History: Places of the Heart: Post 1960 Memorials in Australia: http://www.acph.nicheit.com.au - 9. jaanuar 2014.

Australian Government, Department of Immigration and Border Protection: http:// www.immi.gov.au/media/publications/statistics/comm-summ/textversion/finland.htm - 9. jaanuar 2014.

Australian Maritime Museum, Welcome Wall: http://welcomewall.anmm.gov.au/ 9. jaanuar 2014.

BBC, History, Family history: http://www.bbc.co.uk/history/0/23493076 - 9. jaanuar 2014.

Facebook, Ancestory.com

Facebook, Bli Bli on Maroochy Historical Society Inc.

Facebook, Finnish Genealogy

Family Tree DNA: http://www.familytreedna.com/ - 9. jaanuar 2014.

Immigration Place: http://www.immigrationplace.com.au/ - 9. jaanuar 2014.

National Family History Month, Ways to celebrate Family History Month: http://www. familyhistoryweek.org.au/celebrate - 9. jaanuar 2014 .

Siirtolaisuusinstituutti, Tilastot, Siirtolaisuus 1860-2010: http://www.migrationinstitute. fi/stat/Siirtolaisuus_kartta_1860-2010.jpg - 9. jaanuar 2014.

NSW Migration Heritage Centre, Snowy Mountains Hydro-Electric Scheme: http:// www.migrationheritage.nsw.gov.au/exhibition/newaustralia/building-the-snowy/ 9. jaanuar 2014 .

\section{Kirjandus}

Affleck, Janice \& Kvan, Thomas 2008. Memory Capsules. Discursive interpretation of cultural heritage through new media. Kalay, Yehuda \& Kvan, Thomas \& Affleck, Janice (toim). New Heritage. New Media and Cultural Heritage. Oxon \& New York: Routledge, lk 92-111.

Anderson, Benedict 1983. Imagined communities: Reflections on the origin and spread of nationalism. London \& New York: Verso.

Ashton, Paul \& Hamilton, Paula 2007. History at the Crossroads. Australians and the Past. Ultimo \& Braddon: Halstead Press.

Ashton, Paul \& Hamilton, Paula \& Searby, Rose 2012. Places of the Heart. Memorials in Australia. Melbourne: Australian Scholary Publishing.

Assmann, Jan 2008. Communicative and Cultural Memory. Erll, Astrid (toim). Cultural Memory Studies: An International and Interdisciplinary Handbook. Berlin: Walter de Gruyter, lk 109-118 (doi: 10.1007/978-90-481-8945-8_2).

Basu, Paul 2005. Macpherson Country: Genealogical Identities, Spatial Histories and the Scottish Diasporic Clanscape. Cultural Geographies 12 (2), lk 123-150 (doi: 10.1191/1474474005eu324oa). 
Blank, Trevor J. 2009. Introduction: Toward a Conceptual framework for the Study of Folklore and the Internet. Blank, Trevor J. (toim). Folklore and the Internet. Vernacular Expression in a Digital World. Logan: Utah State University Press, lk 1-20 (http:// digitalcommons.usu.edu/cgi/viewcontent.cgi?article=1034\&context=usupress_pubs 3. märts 2014).

Blank, Trevor J. 2012. Introduction: Pattern in the Virtual Folk Culture of ComputerMediated Communication. Blank, Trevor J. (toim). Folk Culture in the Digital Age. The Emergent Dynamics of Logan: human Interaction. Logan: Utah State University Press, lk 1-24.

Bryceson, Deborah \& Vuorela, Ulla 2002. Transnational Families in the Twenty-first Century. Bryceson, Deborah \& Vuorela, Ulla (toim). The Transnational Family: New European Frontiers and Global Networks. Oxford \& New York: Berg, lk 3-30.

Chamberlain, Mary \& Leydesdorff, Selma 2004. Transnational Families: Memories and Narratives. Global Networks 4 (3), lk 227-241 (doi: 10.1111/j.1471-0374.2004.00090.x).

Creet, Julia 2011. Transnational Archives: The Canadian Case. Journal of Aesthetics \& Culture 3, lk 1-4.

Erll, Astrid 2011. Memory in Culture. Basingstoke \& New York: Palgrave Macmillan.

Fingerroos, Outi 2007. Uuskareliaanit Nyky-Karjalassa. Fingerroos, Outi \& Loipponen, Jaana (toim). Nykytulkintojen Karjala. Jyväskylä: Jyväskylän yliopiston Nykykulttuurin tutkimusyksikkö, lk 16-32.

Fivush, Robyn \& Haden, Catherine A. 2005. Parent-Child Reminiscing and the Construction of a Subjective Self. Homer, Bruce D. \& Tamis-LeMonda, Catherine Susan (toim). The Development of Social Cognition and Communication. New Jersey: Lawrence Erlbaum Associates, lk 315-336.

de Groot, Jerome 2009. Consuming history: historians and heritage in contemporary popular culture. London: Routledge.

Giaccardi, Elisa 2012. Introduction: Framing heritage in a paricipatory culture. Giaccardi, Elisa (toim). Heritage and Social Media. Understanding Heritage in a Participatory Culture. London \& New York: Routledge, lk 1-10.

Guelke, Jeanne Kay \& Timothy, Dallen J. 2008. Locating personal Pasts: An Introduction. Timothy, Dallen J. \& Guelke, Jeanne Kay (toim). Geography and Genealogy. Aldershot \& Burlington: Ashgate, lk 1-20.

Hareven, Tamara 1992. The Search for Generational Memory. Dunaway, David K. \& Baum, Willa K. (toim). Oral History: An Interdisciplinary Anthology. Plymouth: AltaMira, lk 241-256.

Heimo, Anne 2010: Kapina Sammatissa. Vuoden 1918 paikalliset tulkinnat osana historian yhteiskunnallisen rakentamisen prosessia. Helsinki: Suomalaisen Kirjallisuuden Seura.

Heimo, Anne 2011. Folkloristit ja internet - Aave koneessa? Elore 1. Teemanumber Internet ja folkloor, lk 1-5 (http://www.elore.fi/arkisto/1_11/saate_heimo.pdf - 3. märts 2014). Heimo, Anne 2013. Online Memories of Migration. Garda-Rozenberga, Ieva (toim). Oral History: Dialogue with Society / Mutvārdu vēsture: dialogs ar sabiedrību. Riga: Insti- 
tute of Philosophy and Sociology, University of Latvia \& Association of Latvian Oral History Researchers Dzīvesstāsts, lk 27-38 (http://issuu.com/lufsi/docs/oral_history 3. märts 2014)

Henrich, Eureka 2012. Whose Stories Are We Telling? Exhibitions of Migration History in Australian Museums 1984-2001, unpublished PhD thesis, School of Humanities, University of New South Wales.

Henrich, Eureka 2013. Museums, History and Migration in Australia. History Compass 11 (10) (doi: 10.1111/hic3.12090).

Henrich, Eureka (ilmumas). Paying Tribute: Migrant Memorial Walls and the 'Nation of Immigrants'. Moslund, Sten \& Schramm, Moritz \& Petersen, Anne Ring (toim). Migration and Culture: Politics, Aesthetics and History. London: IB Tauris.

Hine, Christine 2000. Virtual Ethnography. London: Sage.

Hirsch, Marianne 1997. Family Frames: Photography, Narrative and Postmemory. Cambridge: Harvard University Press.

Jaago, Tiiu 2002. Family narrative a reverberator of history. Jaago, Tiiu \& Kõiva, Mare \& Kärsnä, Kairika (toim). Lives, Histories and Identities I. Studies on Oral Histories, Life- and Family Stories. Tartu: University of Tartu \& Estonian Literary Museum, lk 405-426.

Jaago, Tiiu 2007. Suguvõsa suulised ajalood. Jaago, Tiiu (toim). Argikultuuri uurimise terminoloogia e-sõnastik. Tartu Ülikool, eesti ja võrdleva rahvaluule osakond (http:// argikultuur.ut.ee - 3. märts 2014).

Jaago, Tiiu 2011. Migration: Stereotypes and Experience from a Folkloristic Viewpoint. Garda Rozenberga, Ieva \& Zirnite Mara (toim). Oral History: Migration and Local Identities. Riga: University of Latvia, lk 69-81 (http://academia.lndb.lv/xmlui/ handle/123456789/10 - 3. märts 2014).

Jenkins, Henry \& Puroshotma, Ravi \& Clinton, Katherine \& Weigel, Margaret \& Robison, Alice J. 2006. Confronting the Challenges of Participatory Culture: Media Education for the 21st Century. Chicago: The MacArthur Foundation (http://www.newmedialiteracies. org/wp-content/uploads/pdfs/NMLWhitePaper.pdf - 15. märts 2014).

Jupp, James 2007. From White Australia to Woomera: The Story of Australian Immigration. Cambridge etc.: Cambridge University Press (doi: 10.1017/CBO9780511720222).

Kalela, Jorma 2012. Making History: The Historian and Uses of the Past. London: Palgrave Macmillan.

Kalela, Jorma 2013. Making History: The Historian and Uses of the Past. Kean, Hilda \& Martin, Paul (toim). The Public History Reader. London \& New York: Routledge, lk 104-128.

Kinnunen, Tiina 2006. Kiitetyt ja parjatut. Lotat sotien jälkeen. Helsingi: Otava.

Kirss, Tiina \& Kõresaar, Ene \& Lauristin, Marju (toim) 2004. She Who Remembers, Survives. Interpreting Estonian Women's Post-Soviet Life Stories. Tartu: Tartu University Press.

Koivukangas, Olavi 1998. Kaukomaiden kaipuu. Suomalaiset Afrikassa, Australiassa, Uudessa-Seelannissa ja Latinalaisessa Amerikassa. Turku: Siirtolaisuusinstituutti. 
Kozinets, Robert K. 2010. Nethnography: Doing Ethnographic Research Online. London: Sage.

Kramer, Ann-Marie 2011a. Mediatizing Memory: History, Affect and Identity in Who Do You Think You Are? European Journal of Cultural Studies 14 (4), lk 428-445 (doi: 10.1177/1367549411404616).

Kramer, Ann-Marie 2011b. Kinship, Affinity and Connectedness: Exploring the Role of Genealogy in Personal Lives. Sociology 45 (3), lk 379-395 (doi: 10.1177/0038038511399622).

Kuhn, Annette 2002 [1995]. Family Secrets: Acts of Memory and Imagination. London: Verso.

Kõiva, Mare 2008. Kahe kultuuri vahel: Virtuaalne väliseesti kogukond. Paar sammukest 24. Tartu: EKM Teaduskirjastus, lk 31-59.

Kõiva, Mare \& Vesik, Liisa 2009. Contemporary Folklore: Internet and Communities at the beginning of the 21st Century. Kõiva, Mare (toim). Media \& Folklore. Contemporary Folklore IV. Tartu: ELM Scholarly Press, lk 97-117 (http://www.folklore.ee/rl/pubte/ee/ cf/cf4 - 3. märts 2014).

Kõresaar, Ene (toim) 2011. Soldiers of memory: World War II and its aftermath in Estonian Post-Soviet Life Stories. Amsterdam \& New York: Rodopi.

Laaksonen, Salla-Maaria \& Matikainen, Janne \& Tikka, Minttu 2013. Tutkimusotteita verkosta. Laaksonen, Salla-Maaria \& Matikainen, Janne \& Tikka, Minttu (toim). Otteita verkosta. Verkon ja sosiaalisen median tutkimusmenetelmät. Tampere: Vastapaino, lk 9-33.

Latvala, Paulina 2001. Suvun suuri kertomus. Muistitietoa itsenäisen Suomen vaiheista. Helsingi: Suomalaisen Kirjallisuuden Seura.

Latvala, Pauliina 2005. Katse menneisyyteen. Folkloristinen tutkimus suvun muistitiedosta. Helsinki: Suomalaisen Kirjallisuuden Seura.

Lehto, Liisa \& Timonen, Senni 1993. Kertomus matkasta kotiin - karjalaiset vieraina omilla maillaan. Laaksonen, Pekka \& Mettomäki, Sirkka-Liisa (toim). Kauas on pitkä matka - kirjoituksia kahdesta kotiseudusta. Helsinki: Suomalaisen Kirjallisuuden Seura, lk 88-105.

Marselis, Randi 2011. Digitising migration heritage: A case study of a minority museum. MedieKultur 27 (50), lk 84-99.

Meethan, Kevin 2008. Remaking Time and Space: The Internet, Digital Archives and Genealogy. Timothy, Dallen J. \& Guelke, Jeanne Kay (toim). Geography and Genealogy. Aldershot \& Burlington: Ashgate, lk 99-112.

Nash, Catherine 2008. Of Irish Descent. Origin Stories, Genealogy, \& the Politics of Belonging. Syracuse: Syracuse University Press.

Peltonen, Ulla-Maija 1996. Punakapinan muistot. Tutkimus työväen muistelukerronnan muotoutumisesta vuoden 1918 jälkeen. Helsinki: Suomalaisen Kirjallisuuden Seura.

Punta-Saastamoinen, Maija-Liisa 2010. Australiansuomalaiset etsivät itseään. Kulttuurisen identiteetin määrittyminen australiansuomalaisessa kirjallisuudessa. Turku: Siirtolaisuusinstituutti. 
Pereajalugu internetiajastul: diasporaa-genealoogia ja jätkuv ajalookirjutusprotsess

Rantala, Jukka 2012. Lasten historiatietoisuus rakentuu perheen muistelukerronnasta. Torsti, Pilvi (toim). Suomalaiset ja historia. Helsinki: Gaudeamus, lk 47-69.

Roberts, Fredric M. 1989. The Finnish Coffee Ceremony and Notions of Self. Arctic Anthropology 26 (1), lk 20-33.

Rosenthal, Gabriele 1998. Question and Method. Rosenthal, Gabriele (toim). The Holocaust in Three Generations. Families of Victims and Perpetrators of the Nazi Regime. London: Cassell, lk 2-7.

Rosenzweig, Roy \& Thelen, David 1998. Presence of the Past. Popular Uses of History in American Life. New York \& Chichester: Columbia University Press.

Samuel, Raphael 1994. Theatres of Memory. London \& New York: Verso.

Samuel, Raphael \& Thompson, Paul 1990. The Myths we live by. London \& New York: Routledge.

Schrager, Samuel 2004 [1998]. What is Social in Oral History? Perks, Robert \& Thomson, Alistair (toim). The Oral History Reader. London \& New York: Routledge \& Taylor \& Francis Group, lk 284-299.

Silberman, Neil \& Purser, Margaret 2012. Collective memory as affirmation: peoplecentered cultural heritage in a digital age. Giaccardi, Elisa (toim). Heritage and Social Media. Understanding Heritage in a Participatory Culture. London \& New York: Routledge, lk 13-29.

Smart, Carol 2007. Personal Life. Cambridge: Polity Press.

Smart, Carol 2011. Families, Secrets and Memories. Sociology 45 (4), lk 539-553 (doi: 10.1177/0038038511406585).

Spoof, Sanna-Kaisa 1999. Suvuista sukuseuroihin: sukuharrastuksen kulttuurihistoriaa. Spoof, Sanna-Kaisa (toim). Suvut seuroissa: tutkimuksia sukuseurojen toiminnasta. Helsingi: BTJ Kirjastopalvelu, lk 9-47.

Srigley, Katrina \& Zembrzycki, Stacey 2009. Remembering Family, Analyzing Home: Oral History and the Family. Oral History Forum d-histoire orale 29, lk 1-29 (http:// www.oralhistoryforum.ca/index.php/ohf/issue/view/10 - 4. märts 2014).

Strandén, Sofie 2010. “Ield, iblod, i frost, i svält”. Möten medveteraners, lottorsoch sjuksköterskors berättande om krig. Åbo: Åbo Akademi (http://urn.fi/URN:ISBN:978-952-12-2507-9 4. märts 2014).

Steedman, Carolyn Kay 1986. Landscape for a Good Woman. A Story of Two Lives. London: Virago Press.

Suominen, Jaakko 2009. Johdannoksi: netin kulttuurihistoriaa. Saarikoski, Petri \& Suominen, Jaakko \& Turtiainen, Riikka \& Östman, Sari (toim). Funetista Facebookiin. Internetin kulttuurihistoria. Helsinki: Gaudeamus, lk 7-22.

Thelen, David 1998. A Participatory Historical Culture. Rosenzweig, Roy \& Thelen, David (toim). Presence of the Past. Popular Uses of History in American Life. New York \& Chichester: Columbia University Press, lk 190-207.

Thomson, Alistair 2011. Moving Stories: An Intimate History of Four Women across Two Countries. Manchester: Manchester University Press. 
Timothy, Dallen J. 2008. Genealogical Mobility: Tourism and the Search for a Personal Past. Timothy, Dallen J. \& Guelke, Jeanne Kay (toim). Geography and Genealogy. Aldershot \& Burlington: Ashgate, lk 115-136.

Torsti, Pilvi 2012. Suomalaiset ja historia. Helsinki: Gaudeamus.

Turtiainen, Riikka \& Östman, Sari 2013. Verkkotutkimuksen eettiset haasteet: Armi ja Anoreksia. Laaksonen, Salla-Maaria \& Matikainen, Janne \& Tikka, Minttu (toim). Otteita verkosta. Verkon ja sosiaalisen median tutkimusmenetelmät. Tampere: Vastapaino, lk 49-67.

Vuorela, Ulla 2002. Transnational Families: Imagined and Real Communities. Bryceson, Deborah \& Vuorela, Ulla (toim). The Transnational Family: New European Frontiers and Global Networks. Oxford \& New York: Berg, lk 63-82.

Vuorinen, Pihla 2001. Perhekertomukset nuorten aikuisten identiteetin rakennusaineksina. Kupiainen, Tarja \& Laitinen Katja \& Vakimo, Sinikka (toim). Minä? Missä? Milloin? Kolmetoista tulkintaa identiteeteistä. Helsinki: Suomalaisen Kirjallisuuden Seura, lk 128-150.

Welzer, Harald 2005. Grandpa Wasn't a Nazi: The Holocaust in German Family Remembrance. International Perspectives 54. American Jewish Committee, lk 1-31 (http://www.ajc.org/atf/cf/\%7BF56F4495-CF69-45CB-A2D7-F8ECA17198EE\%7D/ Grandpa_wasnt_nazi.pdf - 4. märts 2014).

Westerlund, Lars 1999. Sotasurmaprojekti ja sukututkimus. Genos 70, lk 145-152.

\section{Summary}

\section{Family history in the digital age: Diasporic genealogy and participatory history culture}

\section{Anne Heimo}

Keywords: diasporic genealogy, family history, family narrative, Finnish migrants in Australia, migration memories, participatory history culture

Since the 1990s there has been a notable increase in family history research and genealogy in many countries. The development and popularity of information and social networking technology has substantially contributed to this boom in family history. Numerous associations, museums, archives, memorials, the media and online projects are actively participating in the collection of family history and migrant memories, to preserve this increasingly transnational heritage for future generations. It has also resulted in a growing interest to search one's ancestral roots in "the old home country", to search for family members who have migrated to other parts of the world, or to share one's own memories of migration with others. In this article the author focuses on Finnish migrants in Australia and their family history activities. Australia as "a nation of migrants" actively supports its people to engage in family history research and publicly share their experiences of migration with others in many ways as part of its multicultural policy. 